\title{
Julia Wrede
}

\section{Protest polityczny \\ w globalizacji}

DOI 10.35757/CIV.2016.18.16

\section{Wstęp}

Jedno $z$ podstawowych pytań, na które szukają odpowiedzi współczesne nauki społeczne, to pytanie, czy w globalizującym się świecie i globalnej polityce jest miejsce na partycypacje obywatelska, a jeżeli tak, to jak może ona wyglądać, jakie formy przybierać i jak się przejawiać. Globalizacja to wieloaspektowy proces, w którym po pierwsze, zwiększa się liczba wzajemnych współzależności pomiędzy państwami, gospodarkami i obywatelami; po drugie, następuje urozmaicenie zasobu ideowego poszczególnych wspólnot narodowych, a zarazem pewne ujednolicenie postaw i zachowań obywateli; po trzecie, zwiększa się liczba powiązań procesów kulturowych, społecznych, handlowych i finansowych na świecie. Nośnikiem globalizacji, według wielu badaczy, jest demokracja, a ta bez udziału obywateli obejść się nie może i nie powinna. Powstaje zatem pytanie, czy globalna demokracja czy też zglobalizowana demokracja pozostawia przestrzeń dla działań obywatelskich, w tym dla protestu i nieposłuszeństwa.

Intencją artykułu jest ukazanie złożoności ruchów protestu w globalizacji jako wspólnot skupionych wokół różnych celów,

$\overline{\text { Julia Wrede - doktor nauk humanistycznych w zakresie filozofii. Zajmuje sie filozofia poli- }}$ tyki i społeczeństwem obywatelskim, a także filozofia praktyczną. Na co dzień pracuje jako sekretarz redakcji czasopisma naukowego „Muzealnictwo”.

1 Projekt został sfinansowany ze środków Narodowego Centrum Nauki przyznanych na podstawie decyzji numer DEC-2011/01/N/HS5/03340. 
pluralistycznych, integrujących wiele światopoglądów i tożsamości oraz przekraczajacych partykularyzmy narodowe i etniczne. Ruchy te stanowia element szerszego zjawiska, jakim jest globalne społeczeństwo obywatelskie. W nich jak w soczewce skupiają się różne formy realizacji koncepcji globalnego społeczeństwa obywatelskiego, opartej na ideach wolności, globalizacji, demokracji (bezpośredniej), kosmopolityzmu, a także są widoczne zmiany $\mathrm{w}$ modelowaniu tożsamości i tworzeniu wspólnoty politycznej. Ruchy te czerpią te $\dot{z} z$ idei obywatelskiego uczestnictwa, wolności obywatelskich, korzystaja $z$ koncepcji dobrowolnego i podlegajacego umowie sposobu konstruowania wspólnoty politycznej, będąc jednocześnie dziećmi nowoczesnych procesów indywidualizacji, użytkownikami globalnej infrastruktury komunikacyjnej, wyrosłymi w świecie ekonomicznego, społecznego, ekologicznego i demokratycznego ryzyka, poruszającymi się płynnie w świecie wielokulturowym i spluralizowanym.

Istota przemian, $z$ którymi mamy do czynienia $\mathrm{w}$ nowoczesnej polityce jest - nieoczywiste i jednocześnie bardzo głęboko zakorzenione w historii myśli politycznej - odwołanie do udziału obywateli w rządzeniu, nie tylko jednak na poziomie krajowym, narodowym czy lokalnym, lecz również na poziomie globalnym. Idea globalnego społeczeństwa obywatelskiego stanowi więc postulat, wręcz hipote$z e ̨$, związana $z$ nowymi, dającymi się już zaobserwować procesami politycznymi, o których wspomniałam wyżej.

Najprostszym do zaobserwowania przejawem globalnego społeczeństwa obywatelskiego sa więc ruchy społeczne, które przekraczaja granice narodowe. Ruchy te, mimo swojego zakorzenienia w realiach krajowych oraz zainspirowania często przez sprawy o zasięgu lokalnym, stają się symbolicznie (choć nie tylko) wyrazicielami głosu znacznie większej grupy niż ta, w imieniu której początkowo się zorganizowały.

Analiza nowoczesnych ruchów społecznych ukazuje większość istotnych zmian we współczesnej polityce i życiu społecznym, jak chociażby: modyfikacje w kształtowaniu tożsamości, w poczuciu 
przynależności i wspólnoty, rozwój różnych sposobów komunikowania się $z$ innymi członkami wspólnoty i osobami poza nią, przeobrażenia $\mathrm{w}$ zakresie korzystania $z$ mechanizmów demokracji, formułowania postulatów czy wybierania (bądź niewybierania) przywódców. Bliższe przyjrzenie się ważniejszym współczesnym ruchom społecznym - niezależnie od tego, jaka była ich siła, zasięg czy trwałość - pozwala zobaczyć, jak kształtuje się nie tylko praktyczne uczestnictwo obywateli w nowoczesnej (czy wręcz ponowoczesnej) demokracji, ale również w jakiej kondycji sa najistotniejsze pojęcia współczesnej polityki: wspólnota, naród, państwo i demokracja.

\section{Ruchy spoleczne}

Jeśli przyjmiemy, iż globalne społeczeństwo obywatelskie funkcjonuje w warunkach demokracji, wówczas jego istotną cechą będzie nie tylko partycypacja, rozumiana jako udział w rządzeniu, ale także prawo do odmowy, prawo do protestu.

Ruchy społeczne są zjawiskiem, które występuje od bardzo dawna, choć ich nasilenie, jak twierdzą badajacy je socjologowie, przypada na druga połowę XX wieku, gdy nabrały nowej formy i nowego znaczenia. Według Piotra Sztompki wyróżniają się one dwoma czynnikami:

Po pierwsze, sa one ukierunkowane na szczególny cel, jakim jest zrealizowanie jakiegoś rodzaju zmiany społecznej. A po drugie, przebiegaja $\mathrm{w}$ ramach niezinstytucjonalizowanych i niesformalizowanych (a w każdym razie nie $\mathrm{w}$ pełni zinstytucjonalizowanych i sformalizowanych). $\mathrm{W}$ tym sensie sa czymś pośrednim między zachowaniami zbiorowymi (np. w tłumie) a działalnościa zawodowa (np. w urzędzie) $)^{2}$.

Współczesny ruch społeczny można zatem uznać za niesformalizowane działanie oddolne, zainicjowane przez jednostki, które

2 P. Sztompka: Socjologia. Analiza społeczeństwa, Wydawnictwo Znak, Kraków 2012, s. 158. 
angażują się samodzielnie $\mathrm{w}$ działania nastawione na realizację konkretnego celu. Istotna kwestia, którą podkreśla Sztompka, jest brak formalizacji czy też instytucjonalizacji - sa to więc istotnie działania spontaniczne, choć zorganizowane wokół konkretnej sprawy i nastawione na realizację celu przy wykorzystaniu dostępnych środków. Owe cele i środki zostaja ustalone przez sama zawiązująca się wspólnotę, nie są zaś narzucone w sposób odgórny, w postaci sformalizowanej struktury. Nie oznacza to jednak, że ruchy te sa wspomnianej struktury do końca pozbawione. Często bowiem w obrębie danego ruchu pojawia się jakaś mniejsza grupa, skupiająca nowych członków, która działa prężniej, pociagając za soba resztę. Nierzadko też działania ruchów społecznych prowadzą do instytucjonalizacji, przekształcając się $\mathrm{w}$ działania stricte polityczne. Na ten właśnie aspekt ruchu społecznego, który traktuje jako przejaw aktywności zbiorowej, zwraca uwagę Sztompka. Według niego ruch społeczny:

Stanowi kategorię graniczna pomiędzy domena płynnych działań indywidualnych i zbiorowych a bardziej skrystalizowanymi obiektami społecznymi, [...] w obrębie ruchu wyłania się coraz bardziej złożona i utrwalona organizacja, a także jak ruch wbudowuje się w trwałe, szersze struktury państwowe, przekształcając się $\mathrm{w}$ stowarzyszenia, frakcje czy partie polityczne ${ }^{3}$.

Jeżeli więc spojrzeć na te kwestie $z$ perspektywy klasycznego podziału na sferę działań prywatnych i sferę działań państwowych, to nowoczesne ruchy społeczne sa takimi działaniami, których cele sa publiczne (czy wręcz polityczne), lecz same pozostaja w sferze aktywności indywidualnej (czy wspólnotowej, grupowej, zbiorowej). Innymi słowy - chociaż odbywaja się $\mathrm{w}$ przestrzeni publicznej, to korzystaja $z$ środków prywatnych.

W działaniach ruchów społecznych istotna jest też ich „konfliktowość", tzn. fakt, że często sa metoda wyrażania niezadowolenia, czy wręcz próbą wprowadzenia zmian w strukturach władzy bądź

3 P. Sztompka: Zaufanie. Fundament społeczeństwa, Wydawnictwo Znak, Warszawa 2007, s. 173. 
$\mathrm{w}$ funkcjonowaniu systemu politycznego. Krótko mówiąc, ruchy te rodzą się tam, gdzie zachodzi konflikt. Konflikt ten najczęściej wybucha między własnym interesem obywateli a systemem politycznym, ekonomicznym, społecznym, który w pojęciu protestujących ów interes ogranicza bądź wbrew niemu działa.

Aby ruch społeczny powstał i istniał, ważny jest więc - używając słów Neila Smelserana, na którego powołuje się Sztompka w przytaczanym dziele - „sprzyjajacy kontekst strukturalny”, tj. sytuacja, w której $z$ jednej strony pojawiaja się antagonizmy i konflikty, czy też „napięcia strukturalne”, jak nazywa je Smelser, $z$ drugiej zaś istnieja warunki, w których ten rodzaj aktywności społecznej i zbiorowej jest możliwy. Według Smelsera sprzyjajacy kontekst strukturalny występuje wówczas, gdy członkowie danego społeczeństwa maja poczucie wspólnoty, tzn. kiedy sa przekonani o swoim wpływie na kwestie, które staja się celem ich działania, oraz o pełnej ich realizacji. Musi istnieć - przyjmujacc dalej terminologię Smelsera - „świadomość zbiorowa”, rodzaj kontekstu, który umożliwia działanie w sposób zorganizowany i jednocześnie zrozumiały dla otoczenia.

Kontestacja rzeczywistości politycznej, ustalonego porządku politycznego czy społecznego, a nawet wzorów kultury pojawia się w wyniku ukształtowania się wspólnego dla jakiejś grupy, odmiennego niż obiegowy (czy też narzucony przez władzę) sposobu postrzegania rzeczywistości, konstytutywnych dla niej relacji społecznych czy politycznych. Kontestacja, jak twierdzi Paleczny:

[...] prowadzi do wyodrębnienia szczególnego rodzaju grup o charakterze wspólnot, komun, do wzbogacenia i urozmaicenia życia społecznego o zbiorowości subkulturowe ${ }^{4}$.

Same ruchy społeczne podlegaja także swoistej ewolucji, tzn. $z$ upływem czasu się zmieniają. Inną maja postać na początku istnienia, w momencie zawiazywania się, inną gdy nieuchronnie

4 T. Paleczny: Kontestacja, formy buntu we współczesnym społeczeństwie, Nomos, Kraków 1997, s. 10-12. 
organizują się, przyjmując jakieś struktury działania, kiedy przybywa coraz więcej członków bądź kiedy w sposób rzeczywisty zaczynają wpływać na działania aparatu państwowego lub otoczenia. Odmienna od pierwotnej formę przyjmuja także, gdy kończą działalność, czy to tracąc impet niezbędny do podejmowania działań, czy to przeradzając się w zinstytucjonalizowanego aktora sceny politycznej.

Ogólnie można powiedzieć, że nowoczesne ruchy społeczne stanowia niezwykle złożony i dość dobrze już zbadany przejaw aktywności współczesnego społeczeństwa, chociaż zarówno w świadomości społecznej, jak i w społecznym odbiorze czy w relacjach medialnych jest on ujmowany zwykle w tradycyjnych kategoriach, czyli jako rewolucja lub bunt. Nowoczesne ruchy społeczne bowiem nie dość, że dążą do podważenia struktury istniejącego porządku społecznego i politycznego, to także, jak wyżej wspomniano, burza dotychczasowe teoretyczne podziały na państwo i społeczeństwo czy na sferę publiczna i prywatna. Ponadto bez wątpienia uzupełniają obraz społeczeństwa obywatelskiego. Stanowią też przykład aktywności takiego społeczeństwa, polegającej na włączeniu działalności obywatelskiej - indywidualnej bądź zbiorowej, prowadzonej $z$ perspektywy prywatnej - w działania poniekad zarezerwowane dla sfery politycznej. Analogia pomiędzy tego rodzaju działaniem a istota społeczeństwa obywatelskiego, która jest prywatne zaangażowanie w życie publiczne i polityczne, wydaje się być uzasadniona. Rozważając więc kwestie związane ze społeczeństwem obywatelskim, politycznym zaangażowaniem jednostek, osób prywatnych w imię dobra wspólnoty nie sposób pominąc nowych ruchów społecznych. Stanowia one bowiem istotne uzupełnienie obowiazujacej w państwach demokratycznych zasady partycypacji:

Współcześnie podstawowym celem partycypacji publicznej indywidualnych członków i ruchów społecznych jako całości, w państwach demokratycznych, jest dominująca w tym zjawisku zdolność do kontrolowania polityki i jej głównych aktorów [...] [Sfera publiczna] ma to być przestrzeń społecznego dialogu, nie tylko w kwestii polityki, ale także kultury 
i społeczeństw. Udział w publicznej dyskusji jest w równym stopniu prawem każdego człowieka i katalizatorem samookreślenia. Zaangażowanie obywatelskie w życiu społecznym i politycznym stanowi swego rodzaju antidotum na niedostatki i zagrożenia ze strony reprezentatywnego rządu demokratycznego ${ }^{5}$.

W ten sposób potraktowane zjawisko ruchu społecznego zostaje wręcz utożsamione $z$ działaniami, które stanowia o istocie społeczeństwa obywatelskiego: udział w publicznej dyskusji, samookreślenie, zaangażowanie obywatelskie. Można zatem uznać, iż współczesne ruchy społeczne stanowia istotny element w szeroko rozumianej koncepcji społeczeństwa obywatelskiego, a swoim zaangażowaniem wytwarzaja nowy rodzaj przestrzeni publicznej, nową sferę, której ośrodkiem są właściwe dla danego ruchu społecznego idee. Ta nowa przestrzeń publiczna jest zbudowana dzięki deliberacji, dyskusji i konsensusowi, a więc dzięki narzędziom, do których odwołuje się raczej demokracja bezpośrednia niż nowoczesna liberalna demokracja przedstawicielska. Owa nowa przestrzeń publiczna sprowadza się w sensie fizycznym do stworzenia agory, przestrzeni w mieście, gdzie regularnie spotykają się bądź która to przestrzeń okupują uczestnicy ruchu społecznego.

Ruchy społeczne można w rozmaity sposób kategoryzować, klasyfikować i dzielić. Najbardziej ogólną, a zarazem trafna, moim zdaniem, repartycję zaproponował Neil Smelser, dzieląc ruchy społeczne na ruchy zorientowane na normy i ruchy zorientowane na wartości. Ruchy zorientowane na normy to te, które dostrzegaja potrzebe zmian $\mathrm{w}$ istniejacych normach prawnych czy społecznych, ruchy zorientowane na wartości natomiast maja znacznie bardziej radykalny charakter i domagaja się głębokich zmian, u podstaw których powinna zachodzić konieczność innego zdefiniowania wartości, jakimi kierują się członkowie społeczeństwa, czy wręcz żądaja reorganizacji systemu politycznego i społecznego.

5 M. du Vall, A. Walecka-Rynduch: Wyzwania komunikacyjne wobec polityki protestu. PR $w$ ruchach społecznych i ruchach protestu, w: G. Piechota (red.): Public Relations wobec wyzwań współczesności, Krakowska Akademia im. Frycza Modrzewskiego, Kraków 2012, s. $45-46$. 
Oba rodzaje ruchów moga być innowacyjne badź zachowawcze, czyli żądajace wprowadzenia nowych elementów rzeczywistości społecznej do publicznego życia bądź też, przeciwnie, niewprowadzania ich, lecz zachowania status quo lub nawet powrotu do dawnego systemu. Sa więc ruchy skupione wokół protestu przeciwko zanieczyszczeniom środowiska, a więc ekologiczne, sa ruchy obrony praw grup marginalizowanych, nawołujace do zmian $\mathrm{w}$ istniejacym systemie prawnym, a także ruchy ustawiające się $\mathrm{w}$ opozycji do innych ruchów (ruchy i kontrruchy).

\section{Ruchy protestu jako szczególny rodzaj ruchów społecznych}

Współcześnie mamy do czynienia $z$ wieloma przykładami ruchów społecznych i różnymi formami ich zaangażowania w życie publiczne, począwszy od ruchów ekologicznych, obrony praw człowieka, praw pracowniczych, przez ruchy feministyczne, antyi proaborcyjne, koalicje anarchistyczne, ruchy polityczne, wolnościowe, aż po różnego rodzaju ruchy reformatorskie, moralizatorskie czy rewolucyjne. Ich nagromadzenie świadczy zarówno o przytoczonym wcześniej za Smelserem sprzyjającym kontekście strukturalnym, jak i o poszukiwaniu nowego rodzaju poczucia wspólnoty, tożsamości lub też samookreślenia się i manifestacji poglądów przez poszczególnych członków owych grup.

Początków współczesnych ruchów społecznych - czy też ich współczesnego modelu - należy szukać w ruchach lat siedemdziesiątych XX wieku w protestach francuskich studentów w 1968 roku, w Nowej Lewicy w Niemczech, w organizacjach studenckich i w powstaniu Solidarności w Polsce. Zrzeszenia te, zakwestionowawszy zastana rzeczywistość, stworzyły nową, która istotnie zmieniła strukturę społeczną i polityczną.

Dzisiejszych ruchów społecznego protestu jest przede wszystkim więcej i są bardziej różnorodne - już nie tylko skupiają się na kon- 
testacji czy przewartościowywaniu istniejącego systemu, lecz także na organizowaniu różnego rodzaju aktywności o mniej lub bardziej publicznym wymiarze. Ruchy protestu - jako szczególny przypadek ruchów społecznych - swoja główną rolę upatruja w działaniach skierowanych na kontestację istniejącego systemu, zarówno politycznego (co jest najbardziej oczywista ich rola $z$ naszego punktu widzenia), jak i społecznego lub kulturowego, czyli zasad, którymi kieruje się społeczeństwo, jego podstaw i postaw moralnych, tez, jakie jawnie przyjmuje i milczaco zakłada. Podobnie rzecz ma się $z$ ruchami kontestującymi masową bądź też popularną kulturę. Pomijam w tej kategorii różnego rodzaju kontrruchy, które sa niejako $z$ definicji ruchami protestu, gdyż ich kontestacja dotyczy głównie propozycji innych ruchów, tak więc jako takie nie wpływaja istotnie na zmiany w systemie.

Ruchy protestu w globalnym społeczeństwie obywatelskim powstaja podobnie jak w społeczeństwach w obrębie państw narodowych przy pewnych sprzyjających okolicznościach czy też, gdy zaistnieje wspomniany wyżej kontekst strukturalny. Ponadto także dzięki wzrostowi możliwości komunikacji, ułatwiającej zorganizowanie działań.

Ruchy społeczne w XX wieku często formowały się w obrębie określonych grup społecznych czy miejsc, takich jak uniwersytety, zakłady pracy. Istotna więc cecha ruchu społecznego musi być swego rodzaju dostępność, a zatem możliwość łatwego pozyskania członków, uczestników w celu dotarcia do nich z przekazem określającym idee ruchu, a w dalszej kolejności łatwość organizowania konkretnych działań: manifestacji, spotkań, dyskusji. Nie bez przyczyny więc ruchy społeczne najczęściej rodziły się w miastach, a moment ich powstania ściśle wiazał się $z$ czasami, kiedy miasta zaczęły zyskiwać na znaczeniu w obrazie społeczeństwa. Sztompka wymienia jeszcze - obok urbanizacji - inne warunki, które przyczyniły się do tego, że dziś powstaje coraz więcej ruchów społecznych. Sa nimi: industrializacja, która sprzyja kontaktom w zakładach pracy i tworzy wielkie skupiska ludzi, mogacych łatwo się komunikować; upowszechnienie edukacji; rozwój nowoczesnych tech- 
nologii, które w oczywisty sposób przyczyniaja się do ułatwienia przepływu informacji, idei i wspomagaja organizowanie się; rosnaca liczba grup marginalizowanych, wykluczonych, upośledzonych społecznie, w których narasta niezadowolenie; motywacja aktywistyczna i progresywistyczna, tj. nastawienie na działanie, gotowość do brania losu we własne ręce, uznanie własnej odpowiedzialności za wprowadzanie zmian; rozpowszechnienie się demokracji przez wzrost przekonania o konieczności uczestnictwa w życiu publicznym i politycznym, świadomość posiadania wpływu na zasadnicze elementy systemu państwowego i poczucie obowiąku zaangażowania w sprawy polityczne; a wreszcie zaś wolny czas, czyli fizyczna możliwość zaangażowania w coś, co nie dotyczy bezpośrednio i krótkoterminowo spraw utrzymania siebie i rodziny, pracy zawodowej. Warunki te sprzyjaja powstawaniu ruchów społecznych, tworzeniu wspólnot zorganizowanych wokół celu, jak i wokół wartości ${ }^{6}$.

Warte podkreślenia wydaje się to, jak bardzo nowoczesne metody komunikacji wpłynęły nie tylko na możliwość powstawania ruchów społecznych, ale także na rozbudzenie potrzeb ich tworzenia się. W sposób naturalny ruchy społeczne opieraja się na komunikacji i jednocześnie - dotychczas - na geograficznej bliskości swoich członków. Niemniej to, co dotychczas przesądzało o lokalności ruchów społecznych, teraz staje się nieistotne, ze względu na łatwość komunikacji, która zapewniaja nowe technologie informatyczne.

Wspólnota skoncentrowana na celu i wartościach, jakimi kieruje się konkretny ruch społeczny, nie musi być koniecznie wspólnota ograniczona geograficznie, czego przykładem sa często organizacje wywodzące się $z$ ruchów społecznych, mające zasięg międzynarodowy, czego przykładem chociażby sa: Greenpeace, Amnesty International, Oxfam czy ogólnoświatowe koalicje organizacji pozarzadowych, działajacych na rzecz praw człowieka, praw kobiet lub przeciwko marginalizacji, wykluczeniu, a także broniace praw pracowniczych czy dostępu do edukacji itp. Obecnie, wyżej wspomniane ruchy maja charakter w pełni ustrukturyzowany i sa określane

6 P. Sztompka: Socjologia, s. 161. 
mianem organizacji trzeciego sektora, organizacji pozarządowych, lecz ich początki wywodzą się $z$ ruchów społecznych, a szeroki zakres swojej działalności zawdzięczaja poczuciu wspólnoty, które przekracza granice państwowe, będąc niezależne od ograniczeń geograficznych. Stało się to możliwe dzięki rozwojowi środków komunikacji i za ich pomoca pozyskaniu członków.

Jedną $z$ najistotniejszych cech współczesnych ruchów społecznych jest więc łatwość, $z$ jaka powstaja, i warunki, w których moga się sprawnie komunikować zrzeszeni w nich ludzie. To właśnie najczęściej ruchy protestu wykorzystuja narzędzia komunikacji internetowej zarówno do gromadzenia swoich członków w określonym miejscu, jak i później do rzeczywistego wprowadzania zmian. Spora część ruchów społecznych przenosi się obecnie do rzeczywistości wirtualnej, wpływając jednak na świat realny w postaci wysuwania konkretnych postulatów bądź organizowania konkretnych działań, mimo że za pomocą wirtualnych narzędzi. Jak się wydaje, to właśnie dające się ostatnio zaobserwować różne formy społecznego i politycznego protestu, świadcza o tym, iż globalne społeczeństwo jest już nie tylko projektem teoretycznym, ale w coraz większym stopniu staje się polityczną realnością ${ }^{7}$. Warto zatem przyjrzeć się im tutaj bardziej szczegółowo.

\section{Indignadas - Ruch Oburzonych}

Na powstanie ruchów społecznych, które przekraczaja działania prywatne czy grupowe, stając się istotna siłą (czy jest to rzeczy-

\footnotetext{
7 Warto tu przytoczyć także obserwację, którą ciekawie opisuje Anna Nacher (eadem: Rubieże kultury popularnej, Galeria Arsenał, Poznan 2012), dotyczaca kontrkultury i małych, lokalnych ruchów społecznych. Ruchy te, jak sugeruje Nacher, wyjątkowo łatwo łączą się w roje, tzn. w obliczu zagrożenia bądź wspólnego celu potrafią uformować (dzięki łatwości komunikacji) realną siłę, mającą wpływ na rzeczywistość polityczną. W ten właśnie sposób powstały zasadnicze zrywy arabskiej wiosny czy Ruch Oburzonych i Occupy. Na co dzień roje dziela się na niewielkie, lokalne ruchy - ekologiczne, sąsiedzkie czy miejskie - skupione wokół małych społeczności i działające w łatwym do objęcia zasięgu lokalnym, w celu zajęcia się sprawami codzienności i życia prywatnego, bez angażowania się szczególnie w politykę. Co dodatkowo interesujace $\mathrm{w}$ analizie Nacher, to zwrócenie uwagi na fakt, że kontrkultura opierająca się lokalności ma niezwykłą właściwość (bądź przekonanie o tym, że ją ma) przekształcania globalnej rzeczywistości w toku przeprowadzania mikrozmian.
} 
wiście siła polityczna pozostaje kwestia do rozstrzygnięcia), złożyło się wiele okoliczności. Wśród nich można wskazać takie, jak przekonanie o konieczności protestu w stosunku do problemów, dotyczących wielu ludzi, niezależnie od państwa, w którym oni żyją (np. kwestie związane demografia, czyli duża liczba młodych, wykształconych ludzi pozostajacych bez stałego zatrudnienia), ich poczucie solidarności, urbanizacja czy ułatwienia w sposobach komunikowania się. Jeżeli chodzi o tę ostatnia przyczynę, czyli rozwój komunikacji, to warto tu zauważyć, że właśnie nowoczesne media nie tylko walnie przyczyniaja się do powstania i działania ruchów społecznych, lecz także umożliwiają zbudowanie ruchów poparcia poza granicami regionu bezpośredniego odziaływania tych ruchów.

Takie przyczyny złożyły się na powstanie i działanie tzw. Ruchu Oburzonych w Europie. Ruch ten stał się w znacznej mierze odpowiedzia dużej grupy, w szczególności młodych ludzi na apel Stephane'a Hessela, zatytułowany Czas oburzenia! ${ }^{8}$. Hessel, jako były członek francuskiego Ruchu Oporu, w swoim tekście odwołał się do ideałów, którymi kierowała się ta organizacja w okresie II wojny światowej, czyli do niezgody na zastaną rzeczywistość, oburzenia właśnie na niewolę i okupację, i wezwał ludzi do oburzenia na teraźniejsze stosunki społeczne, gdzie - jak sam mówi - dyktatura potęgi finansowej i neoliberalnej gospodarki stanowia zagrożenie dla wolności, równości i solidarności. Hessel wręcz nawołuje do aktywności obywatelskiej i czynnego oporu przeciwko niesprawiedliwości. Pisze bowiem:

Podstawowym motywem Ruchu Oporu było oburzenie. My, weterani ruchów oporu i sił walczących wolnej Francji, wzywamy młode pokolenia, aby ożywiły, przejęły dziedzictwo Ruchu Oporu i jego ideały. Mówimy im: przejmijcie prowadzenie! Oburzajcie się! ${ }^{9}$.

Hessel w swoim apelu wskazuje na Powszechna Deklarację Praw Człowieka (której zresztą był współtwórca) i przekonuje, że powin-

S. Hessel: Czas oburzenia!, przekład P. Witt, Oficyna Naukowa, Warszawa 2011.

9 Ibidem, s. 4. 
na ona stać się podstawą działań dla Oburzonych. Mówi również o kwestiach sprawiedliwości ekonomicznej i za jedno $z$ najważniejszych wyzwań stojących przed Oburzonymi uważa ogromna dysproporcję dochodów pomiędzy najbogatszymi i najbiedniejszymi (do czego potem będzie odwoływać się przede wszystkim Ruch Occupy, mówiąc, że to oni sa 99 proc. najbiedniejszych przy jednym procencie najbogatszych).

Kwestie bezpieczeństwa socjalnego, dostępu do edukacji, służby zdrowia, pracy stanowia w manifeście Oburzonych najistotniejsza część. Hessel jednak na tym nie poprzestaje: wyraża też swoje oburzenie sytuacja w Strefie Gazy, porusza problem terroryzmu, choć zarazem nawołuje do „pokojowej rewolty” czy występuje również przeciwko mediom i masowej konsumpcji.

Manifest Hessela - mimo, że jest niewielka broszura - wywołał bardzo żywy oddźwięk: został przetłumaczony na wiele języków i stał się podstawa ruchów protestu w Europie i Afryce, ma bowiem dość uniwersalną wymowę i jednocześnie operuje dość nośnymi hasłami: „Wszystkim mężczyznom i kobietom, którzy stworzą XXI wiek, mówimy $z$ cała serdecznością: "TWORZYĆ TO STAWIAĆ OPÓR. STAWIAĆ OPÓR TO TWORZYĆ»"10.

15 maja 2011 roku (stąd też funkcjonująca w Hiszpanii nazwa Ruchu 15-M) na ulice Madrytu wyszli studenci i absolwenci, którzy czuli się pozbawieni perspektyw na godna pracę i zarobki. Protesty w Hiszpanii były poczattkiem szerokiej fali manifestacji, która przetoczyła się przez cała Europę, Amerykę, Australię i Azję. Siedem miesięcy później, 15 października 2011 roku, manifestowano aż w osiemdziesięciu dwóch krajach.

Ruch Oburzonych - na większą skalę niż w przypadku tzw. arabskiej wiosny, choć znacznie mniej gwałtownie i dramatycznie - przekroczył nie tylko granice państw, lecz także kontynentów. Istotne było to, że zgromadził ludzi wokół kwestii, które $\mathrm{w}$ tym czasie były niemal uniwersalne, czyli bezrobocia młodych, wykluczenia (przede wszystkim na rynku pracy, ale nie tylko),

${ }^{10}$ Ibidem, s 12. 
kryzysu gospodarczego, ubożenia klasy średniej i pogłębiających się nierówności społecznych.

Bardzo istotna cecha Ruchu Oburzonych jest akcentowanie w nim indywidualizmu, a więc postrzegania świata społecznego przez pryzmat jednostki. Dlatego ruch ten jest budowany raczej jako zbiór indywidualności niż wspólnota. Skutkiem tego założenia sa brak struktury i hierarchii organizacyjnej. Tym, co zaskakuje, jest fakt, że taka organizacja zbiorowości doskonale się sprawdza w praktyce. Ruch nie ma twarzy, nie ma przywódców ani klasycznej struktury władzy. Każdy członek ruchu należy do niego dobrowolnie, na własna odpowiedzialność i indywidualnie odpowiada za to, w jakim kierunku prowadzone są działania ruchu. Takie podejście sprawia, że ruch ten jest deliberatywny, tzn. jego działanie opiera się na wymianie zdań, na dyskusji, na rozmowie, podczas której poruszane sa kwestie dotyczące zarówno najgłębszych idei demokracji, państwa, władzy, jak i istotne dla zgromadzonych problemy i propozycje ich rozwiazania. Uczestnicy hiszpańskiego Indignadas, ale też Ruchu Occupy, o którym będę mówić poniżej, sa wspólnie odpowiedzialni za porozumienie i jednocześnie sa niezawisłymi jednostkami, które prezentuja wyłącznie własne poglądy. Paradoksem jest więc fakt, że istota wspólnoty zbudowanej przez ruch jest absolutny indywidualizm, a więc podkreślanie niejednolitości. Mamy tu zatem do czynienia $z$ zupełnie innym rozumieniem działań zbiorowych niż to, prezentowane przez tradycyjne ruchy społeczne czy partie polityczne, w którym podstawa jest ujednolicenie poglądów. Potrzeba stworzenia wspólnoty sprawiła jednak, że ruch Indignadas prowadził wielodniowe dyskusje dotyczace demokracji, zasad sprawiedliwości społecznej, rozwoju czy ekologii. Jest to powrót do absolutnych korzeni demokracji i jednocześnie czynnik integrujacy członków.

\section{Ruch Occupy}

Emanacja Ruchu Oburzonych jest Ruch Occupy, który w USA zaczał się od protestów przeciwko bezkarności finansowej bankie- 
rów $z$ Wall Street. W powszechnym przekonaniu bowiem bankierzy ci ponosili winę za spowodowanie kryzysu finansowego, którego skutki odczuł cały świat. Ruch Occupy Wall Street stanowi, jak sądzę, przedłużenie Ruchu Oburzonych, a jako przykład nowych ruchów politycznego protestu wydaje mi się być szczególnie interesujacy. Nosi bowiem wiele znamion nowoczesnego ruchu protestu, a przy tym dodatkowo jest $z$ jednej strony odpowiedzia na zglobalizowane problemy, a $z$ drugiej - ruchem, który sam się globalizuje, czyli znajduje poparcie (i naśladowców) w wielu państwach swiata.

Znamienna jest już deklaracja Ruchu Occupy Wall Street. Jej najistotniejsze punkty, które ów ruch definiuja, mówią zarówno o jego uniwersalności - rozumianej tu przeze mnie jako możliwość zastosowania w rozmaitych kontekstach lokalnych (czy też odniesienia do nich) - jak i zarazem w bardzo dużym stopniu o konkretności, wręcz lokalności właśnie. Czytamy bowiem:

Jako wspólnota gromadzimy się, by dać wyraz poczuciu niesprawiedliwości, która dotyczy wielu, musimy więc mieć świadomość tego, co nas połączyło. Formułujemy niniejsza deklarację, by pokazać, że jesteśmy sprzymierzeńcami tych wszystkich, którzy czuja się pokrzywdzeni przez wielkie korporacje. Jako zjednoczony ruch, w następujący sposób widzimy rzeczywistość: przyszłość rasy ludzkiej wymaga współpracy jej przedstawicieli; system musi chronić nasze prawa, a w obliczu jego zepsucia, do jednostek należy ochrona ich własnych praw i praw sąsiadów; demokratyczny rząd czerpie władzę $z$ ludu, a korporacje nie zabiegaja o zgodę, by czerpać bogactwo $z$ wykorzystywania ludzi i środowiska naturalnego. Nie da się osiagnać prawdziwej demokracji, jeżeli jej procedury będa określane przez siłę ekonomiczną ${ }^{11}$.

W tekście deklaracji zwraca uwage przede wszystkim zakres zgłaszanych postulatów i sposób formułowania ich tak, że brzmia niemal jak podszyte teoriami spiskowymi. Nie to jednak wydaje się być najistotniejsze. Znacznie ważniejsze zdaje się być zawarte

${ }_{11}$ Declaration of the Occupation of New York City, przekład własny - J.W., < http://www. nycga.net/resources/documents/declaration/> [dostęp: 19 sierpnia 2014 roku]. 
w tym manifeście przekonanie o nieuchronnej konieczności zmian w systemie. W systemie, który jest oceniany jako niedemokratyczny, uzależniony od gospodarki, a wręcz zależny od konkretnych korporacji, niejako $z$ tylnego siedzenia wpływających na system polityczny w Stanach Zjednoczonych i na całym świecie. Zepsucie demokracji, protest przeciwko neoliberalnym praktykom i podkreślanie konieczności zachowania równości i wolności oraz obrona praw obywatelskich i praw człowieka pokazuja, że Ruch Occupy Wall Street jest spadkobierca zarówno lewicowych ruchów lat siedemdziesiątych, jak i ruchów altergolobalistycznych $z$ lat dziewięćdziesiątych XX wieku. Pojawiaja się w nim również wątki ekologiczne i kwestie równości w dostępie do edukacji czy do leków.

Co ciekawe, podobnie jak w przypadku ruchów arabskiej wiosny czy ruchu Indignadas, podstawowe hasła deklaracji dotycza kwestii, które ewidentnie stały się bardziej aktualne w dobie kryzysu gospodarczego po 2008 roku. W przypadku Ameryki dotyczą raczej kredytów i problemów $z$ ich spłacaniem niż bezrobocia czy braku perspektyw życiowych, jak to było w krajach arabskich czy w Hiszpanii.

Jak jednak podkreśliłam nieco wyżej, hasła formułowane przez Ruch Occupy sa stosunkowo uniwersalne, tzn. pozwalają się utożsamiać $z$ nimi wielu jednostkom/obywatelom i wielu ruchom społecznym, które zresztą chętnie do nurtu Occupy dołączają. Powstało dotychczas wiele „oddziałów” Occupy w całych Stanach Zjednoczonych i w Kanadzie, a podobne hasła regularnie sa podnoszone na manifestacjach niezadowolenia w wielu krajach Europy i Australii. Ruch Occupy okazał się też wyjątkowo trwały. Mimo prób jego zdelegalizowania czy też rozpędzenia demonstrantów ruch - który w dużej części przeniósł się z upływem czasu do rzeczywistości wirtualnej - działa nadal i organizuje, czy też tylko inicjuje, różnego rodzaju akcje.

Jednym $z$ najbardziej charakterystycznych wyznaczników Ruchu Occupy jest jego niezwykle demokratyczna struktura. Stanowi ona jednocześnie punkt odniesienia dla jego członków i element 
będący istota ruchu, a zarazem powód, dla którego Ruch Occupy jest tak niezwykła siła $\mathrm{w}$ zachodnim świecie politycznym. Ciekawe jest również to, że - obok demokratyczności podobnej do tej, która wypracowały w deliberacji ruchy europejskie - Ruch Occupy w USA stara się jednak znacznie bardziej uregulować swój sposób działania. Ruch Occupy, czy też poszczególne obozy ruchu, w trakcie dyskusji i tworzenia projektów i programów spisuja własne kodeksy postępowania odnoszące się do ewentualnych działań. Sa one niezwykle interesujace dlatego, że odzwierciedlaja absolutną horyzontalność struktury ruchu, w którym każdy ma prawo zabrać głos i być wysłuchanym, a każdy projekt musi być przedyskutowany itp. Ponadto kodeksy te stanowia zbiory instrukcji dotyczacych codziennego życia w obozach ruchów i określających funkcjonowanie $\mathrm{w}$ dużej grupie.

W kolejnej deklaracji, w Zasadach solidarności, Ruch Occupy przedstawił mechanizmy i zasady, na jakich opiera się jego działanie:

Jesteśmy autonomicznymi bytami politycznymi, bierzemy udział w akcie pozbawionego przemocy obywatelskiego nieposłuszeństwa, a solidarność opieramy na wzajemnym szacunku, akceptacji i miłości. Silni wspólnotą odzyskanych wartości, wołamy do wszystkich Amerykanów i całego świata „dość!”. Jak wiele kryzysów jeszcze nas czeka? To my jesteśmy 99 proc. i to my postanowiliśmy odzyskać zadłużona przyszłość. Poprzez proces demokracji bezpośredniej jako jednostki zjednoczyliśmy się i opracowaliśmy takie zasady solidarności, które będą dla nas wspólne ${ }^{12}$.

Kwestie „poziomej” struktury ruchu, jego demokratyczności i jednocześnie publicznych działań grupowych, stanowia zasadniczą cechę ruchu i powód, dla którego tak trudno go zdefiniować i zakwalifikować. Niełatwo też odnieść go do sytuacji politycznej, skategoryzować w obrębie istniejącego systemu, tzn. uznać za siłę w strukturach publicznego dyskursu politycznego, gdyż

\footnotetext{
${ }_{12}$ Principles of Solidarity [Zasady solidarności stworzone przez Ruch Occupy New York], przekład własny - J.W., <http://www.nycga.net/resources/documents/principles-ofsolidarity/> [dostęp 19 września 2014 roku].
} 
Ruch Occupy czy też Organizacja 99 proc. wycofują się z niego i kontestujac zastany ład, ustawiaja się w opozycji i jednocześnie w sferze „wiecznej alternatywy” - grup, które niejako z definicji, żywią niechęć do organizacji czy biurokratyzacji, hierarchizacji i strukturalizacji, nie pozwalając klasycznym uczestnikom debaty politycznej podjąć dyskusji ze sobą ani odnieść się w sposób rzeczowy do postulatów przez ruch wysuwanych. Jednocześnie Ruch Occupy zyskuje coraz więcej zwolenników i sam określa siebie i swoich członków jako 99 proc., czyli tę część społeczeństwa, której kosztem bogaca się najbogatsi i która protestuje przeciwko rządom korporacji i neoliberalnej polityce gospodarczej Stanów Zjednoczonych.

Charakterystyczna cechą Ruchu Occupy jest jeszcze owa pozioma struktura, która stawia go niemal dokładnie w miejscu społeczeństwa obywatelskiego, rozumianego po heglowsku, tzn. jako element pośredni pomiędzy zinstytucjonalizowanym państwem i prawem a jednostka, postrzegana $z$ perspektywy prywatności. Occupy podkreśla, że ruch jest zbiorem jednostek, pozbawiona struktury grupa indywidualnych ludzi, którzy działają we własnym interesie na rzecz zmian w systemie państwowym. Ultrademokratyczna struktura bezpośredniego uchwalania postulatów, która zakłada konsensus w miejsce demokracji przedstawicielskiej, służy właśnie zaakcentowaniu indywidualnego podejścia do kwestii będących w istocie sprawami politycznymi, a przynajmniej publicznymi czy społecznymi. Konsensus, osiagany w toku dyskusji, debaty, z która wiąże się konieczność przekonania każdego uczestnika i zapisania wszystkich kwestii podnoszonych przez „członków” ruchu, jest istotowa cecha Ruchu Occupy i stanowi o jego wyjątkowości $z$ punktu widzenia rozważań nad ruchami społecznymi i kwestia społeczeństwa obywatelskiego. Trzeba jednak zauważyć, że konieczność uzyskania konsensusu $z$ jednej strony niezwykle spowalnia działania, $z$ drugiej zaś gwarantuje poczucie wspólnoty i przekonanie wszystkich uczestników debaty o działaniu na rzecz jednej sprawy. Ponadto jest też metodą podkreślenia odrębności 
i odmienności od skorumpowanego, zepsutego, zdaniem członków ruchu, systemu politycznego. Dzięki temu dokonuje się też dość daleko posunięta krytyka demokracji przedstawicielskiej i jednocześnie próba wprowadzenia czy też przygotowania do zmian, które sa konieczne $\mathrm{w}$ daż̇eniu do systemu sprawiedliwego i gwarantującego równość i wolność.

Ta metoda działania - definiujacc Ruch Occupy - sprawia, że nie mieści się on w istniejącym systemie politycznym, nie może się do niego odnieść ani nie pozwala siłom demokracji przedstawicielskiej właczyć go $\mathrm{w}$ istniejące struktury. Jest ruchem stricte obywatelskim, niemogacym - i niemajacym nigdy - przekroczyć granicy pomiędzy tym, co obywatelskie a tym, co państwowe i zinstytucjonalizowane. Brak przedstawicieli, ośrodka, z którym polityczne struktury państwa mogłyby negocjować czy też debatować, sprawia, że Ruch Occupy nie może zostać poddany krytyce jako element systemu.

Skoro postrzegamy Ruch Occupy jako przejaw aktywności obywatelskiej, odwołującej się do pierwowzorów społeczeństwa obywatelskiego, należy się zastanowić, jak dalece jest on "globalizowalny”. Oczywiście, jako ruch, Occupy wydaje się nie poddawać zglobalizowaniu. Trudno sobie bowiem wyobrazić praktyczna możliwość uniknięcia strukturalizacji na skalę światową. Forma działania, jaką przyjmuje Ruch Occupy, konieczność dążenia do konsensusu wszystkich uczestników ruchu, debata i negocjacje pomiędzy poszczególnymi jego członkami jako indywidualnościami - zakłada jego absolutna lokalność i to lokalność na niewielka skalę. Zarazem jednak i postulaty wysuwane przez ruch, i zarzuty, jakie stawia on systemowi demokracji przedstawicielskiej i neoliberalnej oraz zglobalizowanej gospodarce, sa uniwersalne. Dotyczą ogromnej części państw demokratycznych i stanowia punkt styczny $z$ wieloma podobnymi (pod względem postulatów) ruchami na całym świecie. Nie należy się wobec tego dziwić, że kwestie, które stają się uniwersalne dla dużej części nowoczesnego świata (a wywołane sa częściowo przez zglobalizowaną gospodarkę, jak 
również przez zglobalizowaną politykę) wywołują odpowiedź również „zglobalizowana”. Odpowiedź, mieszcząca się gdzieś ponad kwestiami krajowymi i odnoszaca się $z$ jednej strony do spraw jak najbardziej indywidualnych, jednostkowych, takich jak zapewnienie sobie dobrobytu, perspektyw, pracy, edukacji, mieszkania, lecz $z$ drugiej strony tak uniwersalnych, że pozwalających się $z$ nimi identyfikować większej liczbie jednostek niż lokalne grupy społeczne.

Ułatwienia, które niesie ze sobą rozwój nowoczesnych technologii, pozwalaja dotrzeć $z$ przekazem do ogromnej grupy odbiorców i jednocześnie umożliwiaja zbudowanie wspólnoty, grupy, która jest oderwana od ograniczeń geograficznych. Sądzę więc, że ruchy, zarówno takie jak Ruch Occupy, jak też i większość współczesnych ruchów społecznych, można kwalifikować jako element globalnego społeczeństwa obywatelskiego. Obywatelskiego, bo jest to rodzaj zaangażowania, który wychodząc $z$ prywatnych pobudek, stara się wpływać na sferę stricte polityczna, zachowując przy tym niespolityzowany charakter, pozbawiony struktury i hierarchii. Globalnego, bo jest odpowiedzia na problemy wywodzace się z globalizacji: kryzys finansowy, kryzys polityki neoliberalnej, niedomagania demokracji i jednocześnie globalizującego się społeczeństwa. Społeczeństwa, które sięgając po narzędzia ułatwiające komunikację, wiąże w grupę jednostki niezależnie od dzielących je geograficznych odległości. Istotne jest też podkreślenie faktu, który rzeczywiście stawia nowe ruchy społeczne w świetle globalizacji i pozwala nam interpretować ich działania jako działania globalnego społeczeństwa obywatelskiego, a mianowicie: że postulaty wysuwane przez globalizujące się ruchy społeczne nie sa kierowane stricte do rządów państw narodowych, lecz do korporacji, do politycznych organizacji międzynarodowych, do „ludzi całego świata" - co jednoznacznie umiejscawia je w strukturach ponadnarodowych i ponadpaństwowych. 